\title{
TANTANGAN DAN STRATEGI PENDIDIKAN INKLUSI DI PERGURUAN TINGGI DI INDONESIA: LITERATURE REVIEW
}

\author{
Maulana Arif Muhibbin \\ Program Magister Psikologi, Fakultas Psikologi, Universitas Airlangga \\ maulana.arif.muhibbin-2019@psikologi.unair.ac.id
}

\begin{abstract}
Abstrak
Telaah literatur sistematis bertujuan untuk mengetahui tantangan dan strategi dalam mengoptimalkan pendidikan Inklusi di Perguruan Tinggi Indonesia. Artikel dipilih melalui proses penyaringan pada tahun 2015-2020. Review dilakukan pada database online yaitu Google Scholar. Ada 7 artikel yang direview berdasarkan kriteria inklusi. Berdasarkan analisis dari artikel tersebut ditemukan tiga tantangan penerapan pendidikan inklusi di perguruan tinggi serta empat strategi untuk mengoptimalkan layanan pendidikan tinggi inklusi di Indonesia.
\end{abstract}

Kata Kunci: tantangan, strategi, pendidikan inklusi, perguruan tinggi,Indonesia.

\begin{abstract}
A systematic literature review aims to determine challenges and strategies in optimizing inclusive education in Indonesian universities. Articles were selected through a screening process in 2015-2020. Reviews were conducted on an online database, Google Scholar. There were seven articles reviewed based on inclusion criteria. Based on the analysis of the article, there are three challenges in implementing inclusive education in higher education as well as four strategies to optimize inclusive higher education services in Indonesia
\end{abstract}

Keywords: challenge, strategy, inclusive education, higher education, Indonesia

\section{PENDAHULUAN}

Pendidikan inklusi merupakan impelementasi pendidikan di sekolah yang melibatkan semua siswa untuk terlibat dalam proses pembelajaran, semua anggota mendapat perlakukan yang sama sebab mereka memiliki nilai yang sama sebagai anggota sekolah (Moriña, 2017) Inklusi berarti penyatuan siswa normal dengan anak berkebutuhan khusus dengan cara komprehensif meliputi kurikulum, lingkungan dan interaksi sosial di sekolah secara menyeluruh (Yusuf, 2015) Pendidikan Inklusi memandang bahwa anak berkebutuhan khusus tidak dipandang sebagai bentuk kekurangan namun dipahami sebagai kondisi fisik yang berbeda yang dapat melakukan aktivitas dengan cara dan pencapaian yang berbeda pula (Isrowiyanti Isrowiyanti, 2013)Pendidikan inklusi menjamin kesetaraan dan keadilan sosial membuka peluang anak anak berkebutuhan khusus untuk menadapat pendidikan yang berkualitas sehingga individu dapat mengembangkan potensinya dan berkontribusi kepada masyarakat. 
Pendidikan Inklusi merupakan proses belajar mengajar dimana peserta didik difabel menempuh pendidikan bersama dengan peserta didik nondifabel di sekolah reguler dengan modifikasi kurikulum dan pembelajaran yang disesuaikan dengan kemampuan siswa (Setiati \& Yusuf, 2016) Pendidikan inklusi dalam perguruan tinggi di Indonesia diatur dalam peraturan Kementerian Pendidikan dan Kebudayaan No.46 Tahun 2014 mengenai Pendidikan Khusus (Andayani \& Afandi, 2019)Permendikbud tersebut mengatur mengenai konsep, tujuan, sarana prasarana, program belajar dan tenaga pendidik yang harus dipenuhi oleh perguruan tinggi yang akan menyelenggarakan pendidikan inklusi.

Pendidikan inklusif dalam ranah perguruan tinggi diharapkan menjadi tempat dimana mahasiswa difabel dapat belajar, berpartisipasi dan dipandang sebagai individu yang berniali dalam universitas (Morgado et al., 2016) Dalam tingkat perguruan tinggi siswa dituntut untuk berperan aktif memilih kampus yang tepat untuk masa depan mereka, terdapat tiga faktor kunci dalam pemilihan institusi pendidikan yaitu bidang keilmuan, lokasi dan reputasi universitas.

Bagi Mahasiswa disabilitas hal itu berbeda, hal prioritas bagi mereka adalah menemukan perguruan tinggi yang menyediakan layanan sarana prasarana yang sesuai denagan kekhususan mereka, kemudian menentukan apakah ada bidang studi yang diinginkannya, maka mahasiswa disabilitas tentu dihadapkan dengan pilihan yang sedikit dan sangat terbatas (Karellou, 2019)

Tidak semua perguruan tinggi di Indonesia siap mencanangkan program inklusi, hanya kampus ternama yang berhasil mendapatkan award dari pemerintah pusat sebagai kampus yang peduli terhadap mahasiswa perguruan khusus diantaranaya adalah Universitas Pendidikan Indonesia, Universitas Negeri Jakarta, Universitas Negeri Surabaya, Universitas Indonesia, Uniersitas Negeri Semarang, ITS, Universitas Airlangga dan UIN Sunan Kalijaga (Lolytasari, 2016)

Perguruan tinggi disinyalir menjadi tempat diskriminatif apabila tidak dilengkapi sarana sesuai kebutuhan penyandang disabilitas (Morgado et al., 2016) Penyandang disabilitas yang berhasil masuk ke dalam perguruan tinggi masih menghadapi perlakuan yang tidak tepat dan diskriminatif (Andayani \& Afandi, 2019) Hal tersebut dapat berbentuk model pembelajaran yang tidak adaptif, lingkungan sosial yang belum ramah dan sarana dan prasarana yang tidak diakses oleh mahasiswa berkebutuhan khusus. Dalam konteks perguruan tinggi memerlukan waktu yang panjang untuk memenuhi kebutuhan penyandang disabilitas dan menerapkan pendidikan inklusi secara sempurna (Moriña, 2017)

Berdasarkan studi empiris dan data di lapangan mengenai kondisi yang dialami oleh mahasiswa disabilitas, maka kajian literatur review terkait tantangan dan strategi pendidikan inklusi di perguruan tinggi menarik untuk di kaji. Jurnal ini akan menganalisa tantangan dan starategi yang 
dapat diterapkan untuk mengoptimalkan penyelarasan praktik pendidikan dengan prinsip prinsip pendidikan inklusi di Indonesia khususnya dalam ranah jenjang perguruan tinggi.

\section{METODE}

Design penelitian ini menggunakan metode literature review dengan pencarian sistematik pada database google scholar. Peneliti melakukan pencarian dengan meninjau istilah umum dan istilah khusus. Istilah pencarian yang dipakai adalah sebagai berikut: pendidikan inklusi, perguruan tinggi, disabilitas, difabel, perguruan tinggi indonesia.

Terdapat tujuh jurnal yang lulus kriteria sebagai tinjauan literatur. Adapun kriteria jurnal yang dianalisa adalah 1. Penelitian tentang pendidikan inklusi di perguruan tinggi, 2. Subjek penelitian fokus pada mahasiswa Indonesia, 3. Penelitian yang terpublikasi tahun 2015-2020. Identifikasi artikel dilakukan dengan mengecek kecocokan abstrak dengan tujuan telaah literatur. Kemudian full text artikel diidentifikasi dengan menggali informasi yang relevant sesuai tujuan penelitian sistematik review.

Pemilihan literatur juga melalui proses penyeleksian setting penelitian, berdasarkan kriteria dan seluruh proses yang telah dijelaskan sebelumnya penelitian ini memilih 7 literatur untuk diulas. Penelitian ini menghasilkan pembahasan tentang tantangan dan strategi pengoptimalan pendidikan inklusi perguruan tinggi di Indonesia.

\section{HASIL}

Dari artikel yang dianalisa, diketahui bahwa setting penelitian perguruan tinggi inklusi terjadi di Universitas Islam Negeri Sunan Kalijaga Yogyakarta dan Universitas Brawijaya. Penelitian dan implementasi penyelenggaraan pendidikan inklusi perguruan tinggi di Indonesia tergolong rendah hal tersebut dapat dilihat dari sedikitnya kampus yang siap menerima dan membuka layanan mahasiswa dengan berkebutuhan khusus.

Terdapat tujuh jurnal yang membahas tentang pendidikan inklusi di perguruan tinggi. Rangkuman dari jurnal tersebut ada dalam Tabel 1. dibawah ini. 
Tantangan dan Strategi Pendidikan Inklusi di Perguruan Tinggi di Indonesia: Literature Review Maulana Arif Muhibbin

Tabel 1.Ringkasan Temuan Penelitian Tentang Tantangan dan Strategi Pendidikan Inklusi di Perguruan Tinggi.

\begin{tabular}{|c|c|c|c|c|}
\hline \multirow[t]{2}{*}{ Judul, Penulis } & \multirow[t]{2}{*}{ Tahun } & \multirow{2}{*}{$\begin{array}{l}\text { metode penelitian } \\
\quad \& \text { Setting }\end{array}$} & \multicolumn{2}{|r|}{ Hasil temuan } \\
\hline & & & Tantangan & Strategi \\
\hline $\begin{array}{l}\text { Pendidikan Inklusif di Perguruan Tinggi: } \\
\text { Antara Peluang dan Tantangan } \\
\text { Muhamad Yusuf }\end{array}$ & 2015 & Penelitian pustaka & $\begin{array}{l}\text { 1.Pandangan diskriminatif } \\
\text { 2.Kompetensi SDM yang kurang memahami Inklusi } \\
\text { 3.Fasilitas Kampus yang tidak ramah difabe }\end{array}$ & $\begin{array}{l}\text { 1.Ajaran Normatif Agama } \\
\text { 2.Regulasi Pendidikan Inklusi Permendikbud No } 46 \text { Tahun } 2014\end{array}$ \\
\hline $\begin{array}{l}\text { Peran Relawan Terhadap Kemandirian } \\
\text { Difabel di PLD UIN Sunan Kalijaga } \\
\text { Yogyakarta } \\
\text { Neni Rosita }\end{array}$ & 2015 & $\begin{array}{l}\text { Penelitian kualitatif } \\
\text { UIN Sunan Kalijaga }\end{array}$ & & $\begin{array}{l}\text { 1.Relawan Pusat Layanan Difabel UIN Sunan Kalijaga berperan memudahkan mobilitas } \\
\text { mahasiswa difabel dalam proses belajar dan kegiatan kampus lainnya. }\end{array}$ \\
\hline $\begin{array}{l}\text { Pemberdayaan dan Pendampingan } \\
\text { Komunitas Penyandang Disabilitas } \\
\text { Dalam Mengakses Pendidikan Tinggi } \\
\text { Andayani, Muhrisun Afandi }\end{array}$ & 2016 & $\begin{array}{l}\text { Penelitian Lapangan } \\
\text { UIN Sunan Kalijaga }\end{array}$ & & $\begin{array}{l}\text { 1.Pemberdayaan komunitas difabel sebelum masuk ke perguruan tinggi } \\
\text { 2.Pre-University Training } \\
\text { 3.Pendampingan dan Networking siswa difabel menuju perguruan tinggi }\end{array}$ \\
\hline $\begin{array}{l}\text { Aksesibilitas Sarana dan Prasarana bagi } \\
\text { Penyandang Tunadaksa di Universitas } \\
\text { Brawijaya } \\
\text { Tamba Jefri }\end{array}$ & 2016 & $\begin{array}{l}\text { Penelitian kualitatif } \\
\text { Universitas Brawijaya }\end{array}$ & $\begin{array}{l}\text { 1.Infrastruktur Kampus yang belum lengkap mengakomodasi kebutuhan } \\
\text { mahasiswa difabel }\end{array}$ & $\begin{array}{l}\text { 1. Melengkapi infrastruktur kampus sesuai dengan kebutuhan mahasiswa difabel meliputi } \\
\text { pedestrian, ramp dan toilet ramah difabel. }\end{array}$ \\
\hline $\begin{array}{l}\text { Implementasi Model Pendampingan } \\
\text { Mahasiswa Difabel oleh Pusat Studi dan } \\
\text { Laynana Disabilitas (PSLD) Universitas } \\
\text { Brawijaya } \\
\text { Miftachul Jannah, Sihkabuden }\end{array}$ & 2017 & $\begin{array}{l}\text { Penelitian kualitatif } \\
\text { Universitas Brawijaya }\end{array}$ & 1. Ketergantungan mahasiswa difabel terhadap relawan pendamping & $\begin{array}{l}\text { 1.Model pendampingan mahasiswa difabel sesuai dengan jenis hambatan, karakteristik } \\
\text { dan kebutuhan belajar difabel }\end{array}$ \\
\hline $\begin{array}{l}\text { Mewujudkan Akses Pendidikan Tinggi } \\
\text { Bagi Penyandang Disabilitas } \\
\text { Fajar Indra Septiana \& Zulfa Rahmah } \\
\text { Effendi }\end{array}$ & 2019 & Penelitian pustaka & $\begin{array}{l}\text { 1.Belum ada regulasi yang mengatur secara speifik kriteria dan mekanisme } \\
\text { penerimaan mahasiswa baru difabel, berpengaruh terhadap sedikitnya } \\
\text { penyandang disabilitas yang dapat mengakses perguruan tingggi }\end{array}$ & 1.Regulasi pendidikan inklusi Permenristekdikti Nomor 46 Tahun 2017 \\
\hline $\begin{array}{l}\text { Pendidikan Inklusi di Perguruan Tinggi } \\
\text { Studi Kasus di Politeknik Negeri Jakarta } \\
\text { Sastradiharja et all }\end{array}$ & 2020 & $\begin{array}{l}\text { Penelitian kualitatif } \\
\text { Universitas Brawijaya }\end{array}$ & 1.Kesenjangan lembaga yang mampu menerima mahasiswa difabel & 1.Model Pembelajaran kelas Khusus Penuh bagi mahasiswa Difabel \\
\hline
\end{tabular}




\section{PEMBAHASAN}

\section{Tantangan pendidikan inklusi di Perguruan Tinggi}

\section{Paradigma Masyarakat}

Warga lingkungan kampus kerap kali menganggap mahasiswa difabel merupakan individu yang perlu dikasihani dan merepotkan (Yusuf, 2015) Mahasiswa difabel juga kerap mendapati dosen merasa kesulitan mengajar mahasiswa dengan berkebutuhan khusus. Mahasiswa non disabilitas juga menunjukkan gesture menjauhi untuk tidak berkomunikasi dengan mahasiswa Difabel (Ajisuksmo, 2017) Berdasarkan temuan,persepsi komponen sekolah terhadap pendidikan inklusi dirasa rendah dan belum semuanya positif (Setiati \& Yusuf, 2016)

Individu dengan berkebutuhan khusus dianggap sebagai " child as problem " sehingga individu dianggap tidak bisa belajar, berbeda dari yang lain, membutuhkan guru dan lingkungan yang khusus. Pandangan seperti ini akan mempengaruhi kinerja seuruh komponen sekolah dan menumbuhkan rasa pesimis untuk bisa menjalankan pendidikan inklusi dengan optimal (Lolytasari, 2016) Hingga saat ini paradigma yang berkembang adalah medical mindset yaitu menganggap individu penyandang disabilitas adalah orang yang cacat dan perlu kesembuhkan secara pribadi.

Paradigma baru cara memandang disabilitas perlu dilakukan, paradigma baru antara lain social model dan inclusive model (Santoso \& Apsari, 2017)Social model fokus bagaimana melibatkan masyarakat dalam bekerjasama dengan penyandang disabilitas sedangkan inclusive model fokus menghadirkan orang orang dengan disabilitas di tengah pengambilan keputusan dalam kehidupan bermasyrakat. Hal ini cenderung mengakomodir hak hak penyandang disabilitas lainnya.

\section{Manajemen pembelajaran dan SDM}

Persyaratan masuk universitas bagi penyandang disabilitas tidak mudah. Fakultas tidak bisa menerima calon mahasiswa disabilitas disebabkan karena infrastruktur yang tidak mendukung, tidak adanya fasilitas komputer screen reader untuk visual impairmen, komputer untuk tuna rungu dan sedikitnya dosen yang memiliki kompetensi mengajar mahasiswa berkebutuhan khusus (Ajisuksmo, 2017)

Selain kurikulum pembelajaran yang tidak disesuaikan dengan kemampuan Mahasiswa berkebutuhan khusus, faktor lain yang menyebabkan hanya segelintir mahasiswa berkebutuhan 
khusus lolos dalam seleksi perguruan tinggi adalah regulasi (Sastradiharja et al., 2020) Hingga saat ini belum ada peraturan tentang mekanisme penerimaan mahasiswa baru bagi penyandang disabilitas, sehingga banyak penyandang disabilitas yang sebenarnya mampu mengikuti pembelajaran di perguruan tinggi menjadi tidak memiliki kesempatan atau kesulitan mengikuti seleksi penerimaan mahasiswa baru (Septiana \& Effendi, 2019)

Belum adanya modifikasi meliputi kurikulum, cara mengajar, teknologi pendamping dan diktat kuliah menunjukkan rendahnya kesadaran pimpinan, dosen serta staff terhadap kebutuhan mahasiswa difabel, hal ini juga nampak dalam kegiatan KKN, PKL serta bagian akademik di perguruan tinggi yang tidak ramah difabel (Andayani, Ro'fah, 2010)

Kaitannya dengan tersedianya sumberdaya yang memahami prinsip inklusi telah diatur dalam peraturan pemerintah Nomor 19 Tahun 2005 tentang standar pendidikan nasional pasal 41 menyatakan bahwa satuan pendidikan yang melaksanakan pendidikan inklusi harus memiliki tenaga kependidikan yang mempunyai kompetensi menyelenggarakan pembelajaran bagi peserta didik dengan kebutuhan khusus (Kasim et al., 2010)

Prinsip inklusi memerlukan tenaga tenaga ahli dalam penerapannya. Kampus harus menyediakan dosen, tenaga kependidikan, dan para relawan khusus yang mampu memahami kebutuhan para mahasiswa difabel. Akses pembelajaran di perguruan tinggi inklusi membutuhkan modifikasi dalam ranah kurikulum yang dapat dijangkau oleh mahasiswa sesuai prinsip prinsip inklusi.

\section{Aksesibiltas fasilitas kampus}

Universitas bertanggung jawab untuk menyediakan pelayanan dan fasilitas yang layak bagi semua warga kampus. Hak untuk mendapatkan persamaan akses bagi mahasiswa difabel merupakan wujud dari prinsip inklusi. Aksesibilitas ditekankan pada fasilitas umum seperti area parkir, pintu, tangga, lift, jalur pedetrian, perabot, telepon, wastafel, toilet, ramp, rambu jalan dan jalur pemandu(Tamba Jerfri, 2016)

Kenyamanan mahasiswa terganggu dengan tidak terjangkaunya fasilitas ramah difabel, sarana dan prasarana di lingkungan kampus. Elevator, guide blok atau lantai bertekstur belum tersedia dan kontruksi jalan yang tidak mendukung penggunaan kursi roda merupakan sarana yang tidak terlengkapi di kampus (Ajisuksmo, 2017) Penyandang disabilitas khususnya tunadaksa akan sangat kurang nyaman jika sarana prasarana di kampus tidak lengkap, sebab mahasiswa tunadaksa memiliki kekurangan dalam bergerak sehingga membutuhkan alat 
pembantu dan fasilitas penunjang seperti tongkat, kursi roda dan braces atau penahan (Tamba Jerfri, 2016)

Kebutuhan mahasiswa difabel tidak hanya pada fasilitas pembantu di luar kampus, mahasiswa difabel juga membutuhkan ruang kelas yang aksesibel. Seperti dalam memfasilitasi mahasiswa tunanetra, tatak letak ruang kelas perlu diatur termasuk peletakan furnitur, papan kelas, pintu, laci dan perkakas yang runcing di dalam kelas (Andayani, Ro'fah, 2010)

Tidak adanya modifikasi dan renovasi kondisi fisik kampus dengan melengkapi fasilitas sesuai kebutuhan mahasiswa difabel justru akan membahayakan jiwa dan raga mahasiswa tersebut, tidak ada rasa aman bagi mahasiswa difabel dalam kegiatan perkuliahan di kampus.

\section{Strategi pengoptimalan pendidikan inklusi di Perguruan Tinggi}

\section{Regulasi undang undang pendidikan Inklusi}

Payung Hukum atau regulasi undang undang tentang penerapan pendidikan Inklusi di perguruan tinggi telah terbuka. Hal ini memberikan kesempatan kepada penyandang disabilitas untuk meneruskan pendidikan yang lebih tinggi (Yusuf, 2015) Pasal 31 UUD 1945 menjelaskan bahwa pendidikan adalah hak semua warga negara tanpa ada perbedaan apapun (Andayani, Ro'fah, 2010)

Pasal diatas didukung melalui sumber hukum positif Republik Indonesia tentang sistem pendidikan nasional terlatak pada Undang-undangn Nomor 20 Tahun 2003 pasal 4 Ayat 1 : Pendidikan diselenggarakan berdasrakan demokrasi dan tanpa diskriminasi.pasal 11 Ayat 1: Adalah kewajiban pemerintah untuk menyediakan pendidikan yang layak bagi semua warga negara tanpa adanya diskriminasi (Kasim et al., 2010)

Permenristekdikti Nomor 46 Tahun 2017 berisi paradigma baru bentuk keseriusan pemerintah dalam memfasilitasi warga penyandang disabilitas untuk mengenyam pendidikan tinggi. Dalam peraturan ini telah diinstruksikan ke perguruan tinggi untuk memasukkan materi, kajian, atau mata kuliah pendidikan inklusi dalam kurikulum program studi kependidikan (Septiana \& Effendi, 2019) Permenristekdikti Nomor 46 Tahun 2017 diharap menjadi komitmen pemegang kebijakan kampus untuk meningkatkan jumlah mahasiswa penyandang disabilitas untuk melanjutkan pendidikan di perguruan tinggi.

\section{Relawan Pusat Layanan Difabel Perguruan Tinggi}

Mahasiswa Difabel dalam proses belajar membutuhkan tenaga pendamping untuk meningkatkan kemandirian dan mempermudah capaian perkuliahan. Best Practice yang telah di 
terapkan oleh Universitas Islam Negeri Sunan Kalijaga dan Universitas Brawijaya adalah pembentukan relawan di Pusat Layanan Difabel (Rosita, 2015) (Jannah \& Sihkabuden, 2018)

Pendamping yang telah direktrut akan dibekali pendidikan dan latihan mengenai disability awarness dan pelatihan bahasa isyarat untuk berkomunikasi dengan mahasiswa tuna rungu. Hal tersebut penting agar relawan memahami apa kebutuhan dan tanggung jawab mereka terhadap mahasiswa disabilitas(Jannah \& Sihkabuden, 2018)

Secara garis besar tugas relawan terbagi menjadi dua, tugas rutin dan tugas insidentil. Tugas rutin adalah pendampingan belajar atau noteker saat perkuliahan. Contoh tugasnya seperti membacakan, mencatat dan menjelaskan bahan ajar, mendampingi ujian dan sebagianya. Selain itu relawan juga memiliki tanggung jawab pendampingan mobilitas, yaitu membantu mahasiswa difabel untuk mengenali lokasi dan kawasan seputar kampus (Rosita, 2015) Tugas insidentil adalah tugas relawan yang tidak wajib seperti mendampingi mahasiswa difabel dalam event event pusat layanan disabilitas. Private tutor oleh relawan juga diadakan guna membantu mahasiswa difabel memahami materi perkuliahan (Jannah \& Sihkabuden, 2018) Program relawan ini diharap membantu mahasiswa difabel lebih mandiri sehingga mampu bersaing.

Relawan juga dapat bertindak sebagai Peer Counseling atau layanan konseling sebaya bagi mahasiswa Difabel. Mereka juga dapat berfungsi sebagai Peer Tutoring atau pendampingan belajar. Khusus pendampingan belajar biasanya dilakukan oleh teman yang mengambil mata kuliah yang sama dengan mahasiwa difabel tersebut. Bantuan relawan sangat dibutuhkan mengingat sejak awal mahasiwa difabel mendapat tantangan (Setiati \& Yusuf, 2016)

\section{Pendampingan komunitas Difabel}

Program ini merupakan pendampingan untuk mempersiapkan siswa disabilitas atau siswa yang berada di SLB mendapakan kesempatan untuk melanjutkan sekolah ke perguruan tinggi.Persoalan terkait akses menuju perguruan tinggi adalah minimnya informasi dari pihak sekolah, guru dan orang tua tentang hak hak siswa disabilitas untuk masuk perguruan tinggi. Disisi lain, siswa disabilitas sendiri tidak mendapatkan motivasi dan infromasi sehingga ketertarikan untuk melanjurkan sekolah ke tingkat Universitas menjadi rendah(Andayani \& Afandi, 2019)

Program ini telah dilaksanakan Pusat Layanan dan Difabel UIN Sunan Kalijaga dengan melibatkan mahasiswa disabilitas dari UIN Sunan Kalijaga sebagai peer-support dalam komunitas tersebut, sehingga menjadi role model terkait pengalaman mereka mengakses 
perguruan tinggi. Proses pendampingan terjadi dalam tiga tahap, yang pertama adalah tahap assesment yaitu penggalian kebutuha penyandang disabilitas, kedua adalah proses pemberdayaan dimana panitia dan peserta mengikuti sosialisasi, workshop dan monitoring sesuai modul yang ditetapkan kemudian tahap terakhir adalah proses evaluasi.

Pada tahap pemberdayaan terdapat jenis kegiatan yang dapat meningkatkan pemahaman siswa disabilitas untuk melanjutkan pendidikan tinggi, salah satunya adalah Pre-University training dimana siswa difabel diberi pengetahuan dan pengalaman mengenai budaya akademik dankehidupan seputar kampus, hal tersebut akan menyumbang motivasi dan kepercayaan diri calon mahasiswa difabel (Andayani \& Afandi, 2019)

\section{Layanan Perpustakan Difabel Corner}

Perpustakan merupakan tempat sumber keilmuan bagi seluruh mahasiswa perguruan tinggi termasuk mahasiswa difabel. Best Practices yang telah di terapkan oleh UIN Sunan Kalijaga adalah dengan membentuk Difabel Corner yang terintegrasikan dengan layanan perpustakaan agar supaya buku diktat kampus dapat diakses oleh mahasiwa difabel (Andayani, 2018)

Terdapat tiga layanan dalam program tersebut yang pertama adalah koleksi adaptif yaitu koleksi buku populer, referensi kuliah baik dalam bentuk Braille, Softfile, Elektronik Book dan audio book. Layanan kedua adalah teknologi pembantu seperti scan dan komputer dengan aplikasi JAWS yaitu screen reader untuk tunanetra. Layanan ketiga adalah bantuan personal dari relawan pusat difabel UIN Sunan Kalijaga. Bentuk kegiatannya seperti reading assistance dan pendampingan diwilayah perpustakaan (Andayani, 2018)

Beberapa alat bantu adaptif yang perlu disediakan dalam perpustakaan antara lain Scanner, software optical character recognition, closed circuit television alat bantu memperbesar tulisan di buku cetak, digital talking book, buku braile dan buku perbesaran cetak (Andayani, Ro'fah, 2010)

Research library assistance juga penting dalam layanan perpustakaan. Mahasiswa difabel mencari buku melalu online public acces catalogue, setelah menemukan informasi buku yang diinginkan, petugas research library assistance mencarikan buku yang dimaksud sesuai yang dibutuhkan mahsiswa difabel (Setiati \& Yusuf, 2016) Kehadiran layanan perpusatakan yang ramah difabel akan menunjang mobilitas belajar mahasiswa berkebtuhan khusus lebih baik karena mudah mengakses sumber belajar yaitu perpustakaan. 


\section{PENUTUP}

\section{Simpulan}

Berdasarkan tinjuan sistematik terhadap 7 jurnal yang digunakan dalam penelitian ini, dapat disimpulkan tantangan dan strategi pengoptimalan pendidikan tinggi inklusi di indonesia. Tantangan pendidikan inklusi antara lain paradigma masyarakat yang keliru terhadap individu dengan disabilitas, manajemen dan SDM kampus yang tidak memadai dan aksesibiltas fasilitas kampus yang belum menerapkan prinsip inklusi. Strategi yang dapat digunakan untuk mengoptimalkan pembelajaran inklusi di pendidikan tinggi adalah dasar hukum pendidikan inklusi sebagai pijakan implementasi pendidikan, pembentukan relawan pusat disabilitas, pendampingan komunitas difabel dan layanan difabel corner.

\section{Saran}

Penelitian penerapan inklusi pada perguruan tinggi di indonesia belum banyak dipublikasikan pada database international sehingga hanya menggunakan google scholar dalam pencarian artikel. Penelitian selanjutnya diharapkan lebih fokus pada satu tujuan. Diharapkan penelitian yang membahas topik serupa dapat lebih detail dan mendalam mengenai tantangan dan strategi pengoptimalan layanan pendidikan inklusi di perguruan tinggi di Indonesia.

\section{DAFTAR PUSTAKA}

Ajisuksmo, C. R. P. (2017). Practices and Challenges of Inclusive Education in Indonesian Higher Education. 25th ASEACCU Conference on "Catholic Educational Institutions and Inclusive Education: Transforming Spaces, Promoting Practices, and Changing Minds”. Assumption University of Thailand, Bangkok August, 21-27.

Andayani, Ro'fah, M. (2010). Inkludi Pada Pendidikan Tinggi: Best Practices Pembelajaran Dan Pelayanan Adaptif Bagi Mahasiswa Difabel Netra (1st-2010th ed.). Pusat Study Dan Layanan Difabel (PSLD) UIN Sunan Kalijaga.

Andayani. (2018). STUDI KEBIJAKAN KAMPUS INKLUSIF : IMPLEMENTASI PERMENDIKBUD RI NO 46/2014. Jurnal Ilmu Kesejahteraan Sosial, 7(2), 186-207.

Andayani, A., \& Afandi, M. (2019). Pemberdayaan dan Pendampingan Komunitas Penyandang Disabilitas Dalam Mengakses Pendidikan Tinggi. Aplikasia: Jurnal Aplikasi Ilmu-Ilmu Agama, 16(2), 153. https://doi.org/10.14421/aplikasia.v16i2.1178

Isrowiyanti Isrowiyanti. (2013). Mewujudkan Perpustakaan Perguruan Tinggi Yang Ramah Difabel. Baca: Jurnal Dokumentasi Dan Informasi, 34(1), 47-60. https://doi.org/http://dx.doi.org/10.14203/j.baca.v34i1.173

Jannah, M., \& Sihkabuden, S. (2018). Implementasi Model Pendampingan Mahasiswa Difabel oleh 
Pusat Studi dan Layanan Disabilitas (PSLD) Universitas Brawijaya Malang. Jurnal ORTOPEDAGOGIA, 3(2016), 2-5. http://journal2.um.ac.id/index.php/jo/article/download/4970/2675

Karellou, J. (2019). Enabling disability in higher education. A literature Review. Journal of Disability Studies, 5(2), 47-54.

Kasim, E. V. A. R., Fransiska, A., Lusli, M., Siradj, O., Disabilitas, P. K., Sosial, F. I., Politik, D. A. N., \& Indonesia, U. (2010). Analisis Situasi Penyandang Disabilitas Di Indonesia: Sebuah DeskReview. November.

Lolytasari. (2016). Penerapan Ramah Difabel Dalam Pelayanan Perpustakaan Perguruan Tinggi. 3(May), 0-12. https://doi.org/10.13140/RG.2.1.1707.0967

Morgado, B., Cortés-Vega, M. a . D., López-Gavira, R., Álvarez, E., \& Moriña, A. (2016). Inclusive Education in Higher Education? Journal of Research in Special Educational Needs, 16, 639-642. https://doi.org/10.1111/1471-3802.12323

Moriña, A. (2017). Inclusive education in higher education: challenges and opportunities. European Journal of Special Needs Education, 32(1), 3-17. https://doi.org/10.1080/08856257.2016.1254964

Rosita, N. (2015). PERAN RELAWAN TERHADAP KEMANDIRIAN DIFABEL DI PLD UIN SUNAN KALIJAGA YOGYAKARTA. INKLUSI, 2(2), 203-220.

Santoso, M. B., \& Apsari, N. C. (2017). Pergeseran Paradigma dalam Disabilitas. Intermestic: Journal of International Studies, 1(2), 166. https://doi.org/10.24198/intermestic.v1n2.6

Sastradiharja, E. J. S., Farizal, M., \& Maran, S. (2020). PENDIDIKAN INKLUSI DI PERGURUAN TINGGI:Studi Pada Pusat Kajian dan Layanan Mahasiswa Berkebutuhan Khusus Politeknik Negeri Jakarta. 2(1), 101-118.

Septiana, F. I., \& Effendi, Z. R. (2019). 11 Inclusive: Journal of Special Education. Inclusive: Journal of Special Education, $V(01), 11-18$.

Setiati, P. M., \& Yusuf, M. (2016). Volume 3 | no. 3 | 2016. Jurnal Difabel, 3(3), 67-69.

Tamba Jerfri. (2016). Aksesibilitas Sarana dan Prasarana bagi Penyandang Tunadaksa di Universitas Brawijaya. Ijds, 3(1), 16-25.

Yusuf, M. (2015). Pendidikan Inklusif di Perguruan Tinggi: Antara Peluang dan Tantangan. Jurnal Islamika, 15(2), 163-172. 